\title{
ANALISIS SISTEM TENAGA LISTRIK SULAWESI DENGAN PENDEKATAN SEKURITI PEMBEBANAN.
}

\author{
YUSRI AMBABUNGA \\ Sekolah Tinggi Teknik Dharmayadi Makassar \\ Fakultas Teknik, Jurusan Teknik Elektro \\ Email : ambabungayusri@gmail.com
}

ABSTRAK

Penelitian ini bertujuan untuk menentukan batasan sekuritas sistem tenaga pada keadaan awal ketika terjadi beban puncak sebelum dan sesudah kegagalan sistem terjadi ( kontingensi ), mengetahui ada tidaknya pelanggaran batas batas sekuriti sebelum dan sesudah terjadinya kontingensi serta mengetahui kemampuan komponen komponen peralatan sistem yang digunakan pada saat terjadinya kontingensi.

Penelitian ini merupakan studi kasus, yang diawali dengan perumusan masalah, melakukan kajian studi pustaka, pengumpulan data,studi kasus dengan simulasi program serta penarikan kesimpulan.

Dari hasil penelitian diperoleh bahwa beban puncak pada tanggal 02 Juli 2009 pada siang hari mencapai 392,48 MW dan pada malam hari mencapai 487,84 MW. Batasan operasi tegangan sistem yang diijinkan pada saat terjadi kontingensi berada pada kisaran $-5 \%$ sampai $+5 \%$ dan batasan operasi daya sistem yang diijinkan pada saat terjadi kontingensi berada pada kisaran $-10 \%$ sampai $10 \%$.

\section{LOAD SECURITY POWER SYSTEM ANALYSIS OF SULAWESI WITH APPROACH}

\section{YUSRI AMBABUNGA}

\begin{abstract}
This study aims to : Determine the security limit of power system ini initial state when the peak load happens before and after a system failure occurs ( contingency ); investigate whether there is an encroachment of security limits before and after the contingency; and to find out capabilities of the components in the system used at the time of the contingency.

This research is a case study. It was conducted through several stages including research problem formulation, literature review, data collection, case studies with a simulation program, and the draw of conclusion.

The results showed that the peak load on July 2, 2009 reached 392.48 MW in daytime and 487.84 MW in night time. The allowable operational limit of system voltage in the event of continge
\end{abstract}




\section{BAB I}

\section{PENDAHULUAN}

\section{A. Latar Belakang Masalah}

Sistem tenaga listrik berfungsi untuk menyalurkan energi listrik ke beban secara kontinu dalam periode waktu tertentu sesuai dengan kebutuhan. Berdasarkan kenyataan, hal ini tidaklah mungkin dapat dipenuhi oleh sistem tenaga secara kontinu karena adanya gangguan yang bersifat acak yang mungkin terjadi.

Tingkat sekuritas suatu sistem tenaga antara lain tergantung dari komponenkomponennya, konfigurasi sistem ataupun jenis kegagalan yang mungkin terjadi.

Suatu sistem tenaga dapat dikatakan memiliki sistem yang aman jika tidak ada pelanggaran terhadap kendala-kendala sekuritinya, dalam hal ini dapat berupa kendala sekuriti secara umum. Kendala sekuriti yang diperhatikan dalam penelitian ini adalah kendala sekuriti secara umum. Penelitian diterapkan pada Sistem Tenaga Listrik Sulawesi Selatan dan Barat pada saat terjadi beban puncak.

\section{B. Rumusan Masalah}

Berdasarkan latar belakang tersebut di atas, maka dapat dirumuskan permasalahan sebagai berikut:
1. Bagaimana keadaan sistem tenaga pada keadaan awal ketika terjadi beban puncak sebelum kegagalan terjadi

2. Bagaimana keadaan sistem tenaga ketika terjadi beban puncak setelah kegagalan terjadi (kontingensi)

3. Apakah ada pelanggaran batas-batas sekuriti pada sistem tenaga ketika terjadi beban puncak setelah kegagalan terjadi (kontingensi)

\section{Tujuan Penelitian}

Tujuan penelitian ini adalah:

1. Menentukan batasan sekuritas sistem tenaga pada keadaan awal ketika terjadi beban puncak sebelum kegagalan terjadi.

2. Menentukan batasan sekuritas sistem tenaga ketika terjadi beban puncak setelah kegagalan terjadi (kontingensi)

\section{Manfaat Penelitian}

Penelitian ini bermanfaat untuk:

1) Menjaga setiap komponen sistem dapat bekerja dengan baik atau stabil

2) Menjaga kemapuan operasi setiap komponen sistem tenaga tidak melebihi dari kapasitas yang ada misalnya Generator

3) Operator dan pihak-pihak yang bertanggung jawab dalam pengaturan sistem tenaga khususnya sistem tenaga listrik Sulawesi Selatan dan Barat. 


\section{E. Batasan Masalah}

Pada penelitian ini dilakukan batasan-batasan sebagai berikut:

1. Komponen yang digunakan merupakan komponen yang dapat diperbaiki (repairable component)

2. Kegagalan komponen merupakan kegagalan yang bersifat independen atau terjadinya kegagalan tidak mempengaruhi kegagalan lainnya

\section{BAB II}

\section{TINJAUAN PUSTAKA}

Berdasarkan zona fungsional, sistem tenaga listrik dapat dibagi menjadi tiga bagian utama yaitu zona pembangkitan, zona transmisi dan zona distribusi. Dalam mengevaluasi keandalan, ketiga zona tersebut dikelompokkan menjadi tiga hirarki untuk mempermudah dan memperjelas batasan dalam analisis keandalan. Tiga hirarki tersebut adalah Hirarki Tingkat I (terdiri dari fasilitas pembangkitan), Hirarki Tingkat II (terdiri dari fasilitas pembangkitan dan transmisi), serta Hirarki Tingkat III (terdiri dari fasilitas pembangkitan, transmisi dan distribusi).

\section{A. Pendekatan Sekuriti}

Dalam penelitian ini yang ditinjau adalah pendekatan sekuriti secara umum. Kendala-kendala sekuriti merupakan batasan-batasan operasi yang harus dipenuhi dalam pengoperasian sistem tenaga. Kendala-kendala tersebut dapat berupa hal-hal berikut.

a. Tegangan.

Batasan operasi yang harus dipenuhi tegangan di setiap bus beban (PQ bus) adalah: $\mathrm{V}_{\mathrm{i}}^{\mathrm{m}} \leq \mathrm{V}_{\mathrm{i}} \leq \mathrm{V}_{\mathrm{i}}^{\mathrm{M}}$ dengan $\mathrm{V}_{\mathrm{i}}^{\mathrm{m}}$ dan $\mathrm{V}_{\mathrm{i}}^{\mathrm{M}}$ masing-masing merupakan tegangan minimum dan tegangan maksimum yang diperkenankan di bus-i.

b. Aliran daya di saluran.

Batasan operasi yang harus dipenuhi oleh daya yang mengalir melalui saluran $\mathrm{T}$ adalah: $-\mathrm{T}_{\mathrm{L}} \leq \mathrm{S}_{\mathrm{T}} \leq \mathrm{T}_{\mathrm{L}}$ dengan $\mathrm{S}_{\mathrm{T}}$ merupakan daya total yang mengalir di saluran $T$ sedangkan $T_{L}$ merupakan batasan operasi termal dari saluran $\mathrm{T}$.

c. Pembangkitan daya aktif.

Batasan operasi untuk pembangkitan daya aktif adalah: $\mathrm{P}_{\mathrm{k}}^{\mathrm{m}} \leq \mathrm{P}_{\mathrm{k}} \leq \mathrm{P}_{\mathrm{k}}^{\mathrm{M}}$ dengan $\mathrm{P}_{\mathrm{k}}^{\mathrm{m}}$ dan $\mathrm{P}_{\mathrm{k}}^{\mathrm{M}}$ masing-masing merupakan daya minimum dan daya maksimum pembangkit di bus-k.

d. Pembangkitan daya reaktif.

Batasan operasi untuk pembangkitan daya reaktif adalah: $\quad Q_{\mathrm{k}}^{\mathrm{m}} \leq \mathrm{Q}_{\mathrm{k}} \leq \mathrm{Q}_{\mathrm{k}}^{\mathrm{M}}$ dengan $\mathrm{Q}_{\mathrm{k}}^{\mathrm{m}}$ dan $\mathrm{Q}_{\mathrm{k}}^{\mathrm{M}}$ masing-masing merupakan daya minimum dan daya maksimum pembangkit di bus-k.. 


\section{B. Analisis Aliran Daya Metode Newton-}

\section{Raphson}

Analisis aliran daya merupakan suatu bagian penting dalam analisis sistem tenaga. Studi ini sangat penting dalam perencanaan, penjadwalan ekonomis, dan pemantauan sistem yang ada untuk rencana pengembangan masa depan. Masalah dalam analisis aliran daya terdiri dari penentuan magnitude dan sudut fase tegangan tiap bus dan aliran daya aktif dan reaktif setiap saluran.

Dalam penyelesaian masalah aliran daya, sistem tenaga diasumsikan beroperasi pada keadaan seimbang dan digunakan model satu fase. Untuk menghitung aliran daya pada jaringan sederhana dengan bentuk radial dapat dilakukan secara analitik, tetapi untuk jaringan yang lebih rumit diselesaikan secara iterasi. Ada empat kuantitas yang berhubungan dengan setiap bus, yaitu magnitude tegangan $|V|$, sudut fase tegangan $\theta$, daya riil $P$, dan daya reaktif $Q$.

\section{BAB III}

\section{METODOLOGI PENELITIAN}

\section{A. Lokasi Dan Waktu Penelitian}

Penelitian dilakukan pada jaringan $30 \mathrm{kV}, 70$ $\mathrm{kV}$, dan $150 \mathrm{kV}$ sistem kelistrikan sulawesi selatan, yang terdiri 36 bus 43 saluran. Pengambilan data sebagian besar di lakukan di Area Penyaluran dan
Pengaturan Beban (AP2B) PT. PLN (Persero)

Wilayah Sulsel, Sultra dan Sulbar (Sulseltrabar).

Daerah operasi PLN untuk propinsi Sulawesi Selatan dikelompokkan menjadi 6 PLN cabang, yaitu: 1) PLN cabang Makassar, 2) PLN cabang Parepare, 3) PLN cabang Pinrang, 4) PLN cabang Watangpone, 5) PLN cabang Bulukumba, dan 6) PLN cabang Palopo (UP2B PLN, 2002). Sistem kelistrikan yang dioperasikan oleh cabang-cabang tersebut tergabung dalam suatu sistem tenaga listrik yang saling terinterkoneksi satu sama lain yang disuplai oleh pusat-pusat pembangkit besar, seperti Pusat Pembangkit Tello, PLTA (Pusat Pembangkit Tenaga Air) Bakaru, PLTD (Pusat Pembangkit Tenaga Diesel) Suppa, PLTGU (Pusat Pembangkit Tenaga Gas dan Uap) Sengkang, PLTA Bili-Bili, dan beberapa pembangkit kecil yang tersebar di Sulawesi Selatan.

Semua pusat pembangkit y iebutkan di atas, saluran-saluran transmisi, bus, dan level tegangannya selengkapnya dapat dilihat pada diagram satu garis (single line diagram) sistem kelistrikan Sulawesi Selatan di Lampiran

Waktu penelitian : 6 Bulan (Juni - Desember) 2009

\section{B. Jenis Penelitian}

Penelitian ini adalah jenis penelitian deskriptif analitik, yaitu dengan mensimulasi suatu pembebanan sistem tenaga pada state kegagalan 
tertentu, menganalisis, kemudian menggambarkan kondisi tegangan, aliran daya, pembangkitan, dan tingkat pembebanan saluran pada state tersebut. Simulasi diterapkan pada sistem tenaga listrik Sulawesi Selatan dan Barat.

\section{Jenis Data Dan Sumber Data Yang}

\section{Diperlukan}

Data-data akan diambil dengan teknik dokumentasi dan teknik survey di PT. PLN (Persero) wilayah Sulseltrabar. Data-data yang diperlukan antara lain:

1. Data Pembangkit :

- Kapasitas daya (MW atau MVA) dan level tegangan $(\mathrm{kV})$ setiap generator.

- Reaktansi sinkron setiap generator ( $\%$, pu, atau $\Omega)$

2. Data transformator :

- Kapasitas daya (MW atau MVA) dan level tegangan setiap transformator $(\mathrm{kV})$

Reaktansi bocor setiap transformator (\%, pu, atau

$\Omega)$

3. Saluran transmisi :

- Panjang tiap saluran (km)

- Resistansi, reaktansi, dan kapasitansi ke tanah tiap saluran per $\mathrm{km}(\Omega / \mathrm{km})$

- Kapasitas penyaluran daya maksimum (MVA), atau Kemampuan Hantar Arus tiap saluran (A).

4. Beban :
- Data jumlah beban tiap bus (MW)

\section{Instrumen Penelitian}

Alat yang dipakai dalam penelitian ini terdiri dari perangkat keras berupa 1 unit komputer dan perangkat lunak bahasa pemrograman MATLAB dan Microsoft Excel.

\section{E. Langkah-Langkah Penelitian}

Langkah-langkah penelitian dimulai dengan pengumpulan literatur, pengambilan dan pemrosesan data awal, perumusan langkah-langkah analisis data, pembuatan program komputer dengan bahasa pemrograman MATLAB berdasarkan langkah-langkah analisis yang telah dirumuskan, uji coba program komputer yang telah dibuat pada sistem sederhana yaitu pada sistem tenaga 30 bus IEEE (Saadat, H., 2002), serta simulasi dan penerapan program komputer pada jaringan sistem kelistrikan Sulawesi Selatan dan Barat.

Pada penelitian ini, analisis data untuk menentukan nilai kontingensi sistem tenaga listrik Sulsel dilakukan dengan langkah-langkah sebagai berikut:

1. Siapkan data statis yang diperlukan.

Seperti data kapasitas penyaluran daya maksimum saluran, $S_{j k}{ }^{\max }$ untuk setiap saluran $j-k$ dan data-data untuk analisis aliran daya AC lain. Semua data harus dalam satuan per unit (pu) dengan daya dasar yang sama. 
2. Bentuk matriks admitansi bus, $\boldsymbol{Y}_{\text {Bus }}$ dan matriks impedansi bus, $\boldsymbol{Z}_{\boldsymbol{B u s}}$.

3. Lakukan analisis aliran daya AC untuk menentukan keadaan awal sistem.

Ini dilakukan dengan langkah-langkah seperti dijelaskan pada Bab 2.3 Data dinamis berupa aliran daya aktif dan reaktif dari setiap saluran $j-k$ pada keadaan awal, $P_{j k}^{o}$ dan $Q_{j k}^{o}$ (dengan $j, k=1,2, \ldots, \mathrm{n} ; \mathrm{n}=$ jumlah bus), dan $V_{i}$ untuk setiap bus $i$ (dengan $i=1,2, \ldots$, n.) didapat dari analisis aliran daya AC ini.

4. Periksa batas-batas sekuriti statik sistem pada keadaan normal (keadaan awal)

5. Tentukan state kegagalan sistem

6. Lakukan analisis kontingensi, seperti yang telah dijelaskan pada Bab 2.4 untuk menentukan tegangan dan aliran daya saluran setelah gangguan.

7. Periksa batas-batas sekuriti sistem setelah terjadi kontingensi.

\section{BAB IV HASIL DAN PEMBAHASAN}

\section{IV.1 GAMBARAN UMUM SISTEM KELISTRIKAN SULAWESI..}

Dari diagram satu garis sistem tenaga gunakan faktor distribusi untuk memprediksi perubahan arus dan arus keadaan statis yang mengalir pada saluran 5-3 ketika saluran 5-2 lepas dari sistem, yang didahului dengan lepasnya saluran 5-4 karena pemeliharaan. Bandingkan hasilnya dengan yang diperoleh dari hasil perhitungan aliran daya AC. Gunakan data reaktansi dan data tegangan tiap bus yang diperoleh dari hasil studi aliran daya AC pada Tabel 1. (Daya dasar 100 MVA).

Sistem Kelistrikan Sulawesi Selatan dikelola oleh PT. PLN (Persero) Wilayah Sulawesi Selatan, Tenggara, dan Barat. Sistem kelistrikan ini menyediakan daya listrik untuk kebutuhan masyarakat yang berada di Propinsi Sulawesi Selatan dan Sulawesi Barat.

Sistem Kelistrikan Sulawesi Selatan dan Barat terdiri dari 37 buah bus (rel) dan 43 buah cabang saluran yang terinterkoneksi satu sama lain lewat jaringan transmisi dengan tegangan kerja 150, 70 dan $30 \mathrm{kV}$, seperti terlihat pada diagram satu garis (single line diagram) sistem kelistrikan sulawsi selatan (Lampiran 1). Sistem kelistrikan sulawesi selatan ini disuplai oleh beberapa pusat pembangkit, antara lain: i) PLTA bakaru, dengan 2 unit generator jenis Meiden dengan daya terpasang masing-masing $63 \mathrm{MW}$, sehingga total daya terpasang pada PLTA Bakaru sebesar $126 \mathrm{MW}$, ii). Pusat pembangkit Tello memiliki 12 unit pembangkit dengan kapasitas total sebesar 212,72 MW, terdiri dari 2 unit PLTU, 5 unit PLTG, dan 5 unit PLTD.

Di pusat pembangkit tello ini, terdapat empat buah bus, yaitu Bus Tello, Bus Tello 70, Bus 
JDS, Jilid II No. 2, Oktober 2016

Tello 30A, dan Bus Tello 30B. Pada kondisi beban puncak Hari Kamis 02 Juli 2009 yang merupakan data awal penelitian ini, generator-generator yang terhubung pada bus Tello antara lain: PLTG GE 1 \& 2, PLTD SWD 1\& 2, PLTD Mitshubisi $1 \& 2$, dan PLTD Sewatama dengan kapasitas terpasang total 131,8 MW dan daya mampu total hanya 99 MW. Pada bus Tello 70, terhubung generator PLTG Alsthom 2 dengan kapasitas terpasang 20,1 MW. Pada bus Tello 30A, terhubung generator PLTG Westcan dengan kapasitas terpasang 14,47 MW. Generator-generator yang terhubung di bus Tello 30B adalah PLTG Alsthom 1, PLTU 1, dan PLTU 2 dengan kapasitas daya terpasang total 46,35 MW. Kapasitas daya terpasang masing-masing bus dan kapasitas daya terpasang total pada sistem kelistrikan Sulawesi Selatan selengkapnya dapat dilihat pada Tabel 1 .

Disamping kedua pusat pembangkitan tersebut, masih terdapat beberapa buah pembangkitpembangkit kecil yang tersebar dan terinterkoneksi pada saluran distribusi $20 \mathrm{kV}$ dengan total kapasitas terpasang 107,69 MW.

Sistem ini juga terinterkoneksi dengan pusat pembangkitan listrik swasta PT. Makassar Power dan PT Energi Sengkang. PT. Makassar Power yang berlokasi di Suppa Kabupaten Pinrang dengan memiliki enam buah PLTD dengan total kapasitas 64.8 MW, yang terhubung di bus Suppa. Sedangkan PT. Energi Sengkang memiliki empat buah PLTGU dengan total daya terpasang 195 MW yang terhubung di bus Sengkang.

\section{IV.2 DATA PENELITIAN}

Data-data mentah yang diperoleh dari Area Penyaluran dan Pengaturan Beban (AP2B) Sistem Sulawesi Selatan, PT. PLN (Persero) Wilayah Sulseltrabar berupa : Single Line Diagram Sistem Sulawesi Selatan dan barat (Lampiran 1), data unit generator (Lampiran 2), data transformator (Lampiran 3), data impedansi penghantar, (Lampiran 4), line construction types (Lampiran 5), dan data beban dan aliran daya sistem Sulawesi Selatan pada saat terjadi beban puncak tanggal 02 Juli 2009 (Lampiran 6).

Berdasarkan data operasi beban puncak tanggal 02 Juli 2009, kemudian disusun seperti pada Tabel 4.1 dan Tabel 4.2. Pada Tabel 4.1, diperlihatkan nomor bus dalam perhitungan, nama bus, kode bus, level tegangan, jumlah beban, injeksi MVAR, dan daya terpasang dan daya mampu pembangkit pada tiap bus. Data Kode Bus adalah kode yang digunakan dalam perhitungan. Untuk 1 adalah Slack Bus, 2 adalah bus pembangkit ( $P V$ bus) dan kode 0 adalah bus beban ( $P Q$ bus..Pada Tabel 4.2, diperlihatkan data nomor saluran dalam perhitungan, nama saluran, resistansi (R), reaktansi (X), 1/2 suseptansi ke tanah (1/2 B), MVA limit, dan jumlah saluran tiap fase. Resistansi (R), reaktansi $(\mathrm{X})$, dan $1 / 2$ suseptansi ke tanah $(1 / 2 \mathrm{~B})$ tiap saluran dinyatakan dalam satuan per unit (pu) dengan daya 
dasar 100 MVA dan tegangan dasar sesuai dengan tegangan kerja masing-masing saluran. MVA limit adalah daya kompleks maksimum (MVA) yang dapat disalurkan oleh saluran.

\section{IV.3 SIMULASI DAN ANALISIS HASIL PROGRAM ALIRAN DAYA}

Dalam melakukan perhitungan

kontingensi sistem Sulsel, terlebih dahulu harus dilakukan analisis aliran daya untuk menentukan keadaan awal sistem (base case). Data keadaan awal meliputi besar daya aktif yang mengalir pada tiap saluran dan besar tegangan tiap bus pada kondisi pembebanan awal sebelum melakukan transfer daya. Dengan demikian, walaupun penelitian iini tidak bertujuan untuk mengetahui aliran daya normal, namun analisis aliran daya tetap harus dilakukan.

Aliran daya setiap saat pada sistem selalu berubah, karena beban setiap saat juga berubah. Dalam penelitian ini, analisis aliran daya dilakukan pada kondisi beban puncak tertinggi yang pernah terjadi pada sistem kelistrikan Sulawesi Selatan sampai pada saat penelitian ini berlangsung (beban puncak siang dan malam), yaitu pada Hari Kamis tanggal 02 Juli 2009 jam 19.00.

\section{BAB V}

\section{KESIMPULAN DAN SARAN}

\section{A. Kesimpulan}

Hasil simulasi dan pembahasan pada penelitian ini, maka diperoleh suatu kesimpulan bahwa a. Pada kondisi beban puncak siang dan beban puncak malam tertinggi yakni pada pada pukul 12 Wita (siang hari) dan pukul 19.00 Wita (malam hari) sebelum kontigensi sistem dalam keadaan normal yang berarti bahwa supali daya dari pembangkitan ke beban masih mampu dilayani.

b. Kondis pembebanan saat beban puncak siang dan beban puncak malam tertinggi yakni pada pada pukul 12 Wita (siang hari) dan pukul 19.00 Wita (malam hari) setelah kontigensi sistem dalam keadaan tidak normal lagi karena mengakibatkan terjadinya perubahan besaran tegangan, kapasitas pembangkit, dan menaikkan rugi-rugi serta ketidakmampuan penghantar.

c. Keadaan sistem setelah kontigensi dengan memperhatikan batasan-batasan sekuriti yang ada, maka sistem Sulselbar mengalami over voltage, overloading dan ketidakmampuan pembangkit mensuplai daya ke beban sehingga dibutuhkan penambahan suplai dan penambahan saluran pada saluran yang mengalami overloading dan pengurangan kapasitor (menambahkan reaktor) pada lokasi bus yang over voltage.

\section{B. Saran}

1. Kontigensi yang diuji dalam penelitan ini hanya pada 3 kasus untuk kondisi beban puncak siang dan beban puncak malam, sehingga diharapkan 
pengujian dilakukan untuk lokasi-lokasi yang berbeda untuk mendapatkan hasil yang lebih akurat.

2. Kestabilan system setelah kontingensi

dibutuhkan simulasi lain sebagai pembanding agar

simulasi ini lebih akurat, misalnya menggunakan

ETAP powerstation atau software yang lain

\section{DAFTAR REFERENSI}

1. Probabilistic security analysis of bilateral transaction in a deregulated environment, J. W. M. Cheng, D. T. McGillis and F. D. Galiana, IEEE Trans. On Power Engineering, Vol 14, No. 3, pp. 1153-1159, August,1999

2. Models for probabilistic power transmission system reliability calculation, $B$. Bak-Jensen, J. Bech, C. G. Bjerregaard and P. R. jensen, IEEE Trans. On Power Engineering, Vol 14, pp August,1999

3. Composite reliability evaluation by sequential Monte Carlo simulation on parallel and distributed Processing environment, C. L. T. Borges, D. M. Falcao, J. C. O. Mello and A.C. G. Melo, IEEE Trans. On Power Engineering, Vol 16, pp. 203-209, May,2001

4. Probabilistic evaluation of voltage stability, Saleh A. and Roy Billinton,IEEE Trans. On Power Engineering, Vol 14, February,1999

5. Power system stability control, Praba Kundur, New York, McGraw Hill, Inc. 1994.

6. Reliability evaluation of power system, Roy Billinton, New York, 1990

7. Power system reliability evaluation, Roy Billinton, New York,1982

8. Voltage stability of electric power system, Thierry Van Cutsem and Costas Vournas, Kluwer Academic publisher, 1998

9. Power system Analysis, Hadi Saadat, McGraw Hill, 2002
10. Power generation, opration and control, second edition, Allan J. Wood, Bruce F. Wollenberg, John wiley \& Sons.

Inc., 1996 